\title{
The Educational Potentialities of the Virtual Learning Environments Moodle and Canvas: A Comparative Study
}

\author{
Márcia Gorett Ribeiro Grossi, Michelle Cristina Almeida de Souza Elias, Camila Macedo Chamon, and \\ Débora Cristina Cordeiro Campos Leal
}

\begin{abstract}
The advancement of digital information and communication technologies allowed the development of Virtual Learning Environments, which are the spaces where classes offered in distance education take place. Currently there are several virtual learning environments, but the most noteworthy are Moodle and Canvas, which are software that have open programming codes and are freely accessible and provide features such as usability, reliability and mobility. That is why these virtual environments have been adopted by many educational institutions in Brazil. Thus, the present study aimed to compare the technological parameters of the Virtual Learning Environments Moodle and Canvas, in order to facilitate the choice of a virtual environment to be used for educational purposes. It was chosen the qualitative, exploratory and descriptive research which was carried out in 2017. At the end of the research it was possible to realize that both Moodle and Canvas present similar evaluations. However, Canvas was more complete, collaborative and intuitive interface in the results analyzed, in relation to Moodle. In addition, Canvas uses a programming language more modern than Moodle, presenting an updated technology: cloud computing, which represents an advantage over Moodle.
\end{abstract}

Index Terms-Distance education, virtual learning environments, moodle, canvas.

\section{INTRODUCTION}

Education to Distance $(\mathrm{EaD})$ is a teaching modality that has been growing fast in the world. This growth can also be noticed in Brazil, where enrollment in distance courses reached a total of $3,868,706$ in 2014 , of which $519,839(13 \%)$ are enrolled in fully regulated courses, 476,484 (12\%) in online/face-to-face regulated courses or $\mathrm{EaD}$ courses of face-to-face and 2872383 (75\%) in free courses [1]. And, these numbers increased in 2015: "enrollment revealed that the $\mathrm{EaD}$ is on charge at least of 5,048,912 students in the most varied areas of knowledge, academic levels and types of courses", representing an increase of more than $30.5 \%$ during the period 2014 to 2015 [2].

The development and advancement of Digital Information and Communication Technologies (TDIC) are responsible, in great part, for this growth. These technologies have been responsible for the daily growth in the number of software and platforms with several educational proposals for the distance learning modality, increasing the interaction among the EaD actors, such as teacher-students, tutors-students and students- students.

Manuscript received November 2, 2017; revised December 29, 2017

The authors are with the Federal University of Minas Gerais, Brazil (e-mail: marciagrossi@terra.com.br, micheleng.bio@gmail.com, cmchamon@gmail.com, deboracristinaleal@hotmail.com).
Apart from this, it seems that, alongside with this vision, in the EaD, technology is the only means of communication [3]. Technology is also responsible for the development of Virtual Learning Environments (VLE), which are the spaces where learning relationships take place. In this way, VLE appear as the trademark of $\mathrm{EaD}$ [4]. These virtual environments are marked with features such as flexibility, interaction and several pedagogical possibilities and are defined as: Computer systems available on the internet, intended to support activities mediated by information and communication technologies [5]. For the author, VLE present information in a tidy way widening the interactions between people and knowledge objects.

Nowadays, there are various virtual environment options available to educational institutions. They may choose VLE according to their pedagogical needs, either for the management of the didactic contents of the courses, for the administration of the courses and for the constant monitoring of the students' academic paths. In addition, the choice of a VLE goes through the financial question because there are free of charge (open and free) and commercial (paid) virtual environments.

This study focussed of interest was the Modular Object-Oriented Dynamic Learning Environment (Moodle) and Canvas. Then, the question is: how unlike are these two virtual environments?

In this sense, the present study aimed to compare the technological parameters of VLE Moodle and Canvas, in order to facilitate the choice of a virtual environment to be used for educational purposes.

It is worth mentioning that the choice of VLE Moodle and Canvas was due to these are free software, which have open programming codes and are free of charge. Another fact for these choices was due to its features such as usability, reliability and mobility, which make these VLE have been adopted by many educational institutions.

However, it was verified that there are still no studies comparing them, as verified through a consultation held in 2017 at the Bank of Theses and Dissertations of the Coordination of Improvement of Higher Education Personnel (CAPES), as well as in its Portal of Periodics. The consultation followed the ahead steps:

1) Selection of the researches published in the last five years between 2013 and 2017. The following keywords were used: Canvas, Moodle, Canvas and Moodle and Comparison between virtual learning environments, VLE-Moodle and VLE-Canvas.

2) Regarding the Moodle, 2,735 records were found, being 351 dissertations and theses and 2,404 journals. Already on the Canvas, several records were located, but they 
dealt only with a business model also called Canvas and only a master's thesis that dealt with education. Therefore, 2,756 study registries were located.

3) Selection of works that refer effectively to the researched theme, that is, comparison between Moodle and Canvas. For this, the title, the keywords, the abstract and, in some cases, the complete work of the selected records were read. However, of the 2,756 records found, none were identified that actually compared these two environments. All in all, this result shows the need for research on the subject and, thus, the relevance of this article.

\section{THEORETICAL REFERENCE}

\section{A. Virtual Learning Environments}

The evolution of technology, have re-elaborated and reconfigured several forms of interaction and communication in various sectors of life. Going beyond, [6] presents the idea of the intellectual technology that engenders the new way of thinking the world, of understanding learning and its relations with this world. From this perspective, the field of education was not immune to technological advances. There are many (re) created tools that promise to facilitate and promote the teaching and learning process. In this constant technological evolution, $\mathrm{EaD}$ plays an important role, especially with the development of the internet, which was one of the main factors for the expansion of this type of teaching.

In this context, the roles of teachers, tutors, and students are reconfigured, since their school space becomes VLE, defined as content management and learning environments based on educational platforms. Thus, [7] complements the concept of [5], already set out above, about VLEs: These are environments, usually web-based, that are intended for electronic management of courses and virtual learning activities. They are not restricted to courses at distances, because they can also be used in blended learning or as support for face-to-face activities. VLE also offers a variety of resources, ranging from simple content page presentations to comprehensive management systems, including secretarial and e-commerce services [7].

In this way, virtual learning environments should prioritize ease of use and navigation, favoring interactivity: student-technologies, student-teacher, student-student and student-content [8]. According this thinking, the tools available in VLE should be presented in a stimulating and friendly way, in order to invite and encourage the student while browsing the virtual platform. Therefore, the importance of knowing how pedagogical resources are arranged, developed and articulated with their methodologies, communications and interactions, in distance courses that take place in virtual environments [9].

In its studies [7] highlights as pedagogical resources of an VLE: content management; individual and collective work area; e-mail; instant message; chat room; Discussion Forum; billboard; virtual slate; resource sharing and evaluation. Finally, pedagogical resources which functions are to contribute so that the process of teaching and learning happens in a fluid and continuous way. All of these elements justify the need for EaD to require an interdisciplinary work team, which is involved in the elaboration of didactic material, the implementation of the media and the production of learning objects.

However, for VLE to really be a potential tool for distance learning, some technological parameters must be present in this virtual environment. Thus, five technological parameters were highlighted in this study. These were chosen due to the fact that they aim to guarantee the user a simple layout with friendly interfaces to allow easy navigation through the environment, as well as good communication between them. This choice was also based on the VLE comparison software financesonline.com. The parameters are:

1) Interoperability: this is the ability to communicate between systems. In VLE the functionalities need to interoperate and collaborate, resulting in the exchange and reuse of functionalities. Interoperability between educational environments ensures the promotion of spaces able to integrate the areas of knowledge [10]. Finally: platforms should enable interoperability between educational environments in order to provide reuse of knowledge and greater integration of people [11].

2) Usability: refers to the development of efficient and friendly interfaces that facilitate navigation in VLE. And clarifying [12] the term usability is the ability of the product to be used by specific users to achieve goals with effectiveness, efficiency and satisfaction in a specific context of use. In addition, the main goal of usability is to minimize learning time; the users' impatience to perform tasks; low use of tools; the user errors when browsing the software and, consequently, the low performance [13]. Summing up, usability has several components and is associated with the five attributes: being easy to learn, being efficient in use, being easy to remember, having few errors and being pleasant [14].

3) 3. Performance: refers to the involvement and final results obtained by the students through the use of VLE. Therefore, to achieve good learning outcomes, it is necessary to monitor and evaluate the interactions established between student-teacher, student-tutor and student-student [15]. Given this, an VLE needs to include tools that quantitatively and qualitatively indicate the participation and involvement of students. Namely: number of posts in forums, relevance of posts, time interval between posts, number of hits, among others.

4) Digital learning tools: these help the teaching and learning process as they increase the possibilities of access and construction of knowledge, through dynamic and interactive contents. These digital tools are present in the VLE and assist in the communicative process among its users, as well as in the methodological strategies used such as teleconferences, videoconferences, chats, discussion forums, electronic mail, interactive media, videos, games, among others [16].

5) Management tools: VLE must present an entire structure of management and administration of online activities. For its administration there are mechanisms of organization such as, warnings, lesson plan, elaboration of tasks and examinations for evaluation, monitoring of the participation and contribution of the students, access 
to notes and history of the students, tools of content updated, dissemination of new activities, as well as creating statistical reports that allow administrators to monitor student progress and access to VLE.

Therefore, we must consider these five technological parameters when doing an analysis of a virtual learning environment and thus ensure the good functionality of this environment for teaching.

\section{B. Moodle}

Moodle is a free online learning management virtual environment and allows educators to create their own private portal with their distance learning courses that can be done anytime, anywhere. It was developed in 1999 by Martin Dougiamas, an Australian student at Curtin University of Technology, whose premise was to create free software, inviting users to interact and modify it constantly. Soon after, it was led and coordinated by an Australian company of 30 developers that is funded by a network of more than 60 partner service companies distributed around the world called Moodle HQ.

It is also supported by an active international community, made up of a group of Moodle certified developers and partners who are dedicated full time. The project is guided by open collaboration and ongoing support from the community performing its fast bug corrections and enhancement solutions [17].

Its programming and installation are simple and easy to interact with the user, because it requires few computational resources and its interface is based on simple technology browsers. On their digital tools, they allow for asynchronous communication, such as forums, mail, tasks, journals, and synchronous communication of chats. Also, it has several modules for teaching and learning process, such as Resources, questionnaires, activities, evaluation laboratory, among others. Regarding mobility, there is currently a mobile version, which is available for download on the Android and IOS (Apple) versions.

\section{The Canvas}

This virtual environment was launched in 2012 by educational technology company based in Salt Lake City in Utah. It was created by Josh Coates Canvas named Learning Management Systems (Canvas), which is a virtual online learning environment.

Its architecture and design are customizable allowing users flexibility in how to organize their virtual learning environment. It also allows communication between teacher and student and tutor and student to be emphasized and makes both parties work easily during the learning process.

For the benefit of students Canvas allows viewing notifications, present documents, interact with the learning materials provided to them and share the account with social media Facebook and Twitter. While for educators, Canvas provides an environment for creating diverse learning methodologies and providing feedback, integrating videos, blogs, wikis, and other education channels, while observing the progress of their students [18].

Another important feature of this sort of VLE is that it is designed to be used in the cloud. It does not need hosting, nor upgrades, versions, data back-up, and not be harmed when servers fail. This gives users access to the Canvas via the Web. According to mobility, it can also be accessed through mobile devices.

\section{Methodology}

This study opted for qualitative scientific research, carried out in 2017. As sort of research, it was exploratory and descriptive and was carried out in three stages:

Step 1: Investigation of the number of VLE Moodle and Canvas users.

Step 2: Selection of technological parameters that served as a basis for comparing VLE.

Step 3: Analysis of the characteristics of VLE, using the most current version available from each platform. It was used the online Finance data, the official Moodle sites and Canvas. Also, observations were made in the virtual environments themselves. It is worth mentioning that, for the analysis of the parameter interoperability, it was necessary to conduct an interview with a professional of Software Engineering for a better understanding of the technical aspects of this parameter. The choice of this professional happened due to the ease of access to them, since they work in the same institution where the researchers study and work. Then, with these analyzes it was possible to make a comparison between Moodle and Canvas, considering the five technological parameters:

1) Interoperability.

2) Usability.

3) Performance.

4) Digital tools for learning.

5) Management tools.

\section{ANALYSIS AND RESULTS}

Step 1: From the survey on the official websites of these AVA, it was possible to collect the following data: Moodle is a platform used in 234 countries and has 107,019,971 users worldwide. Canvas has 18 million users worldwide. At first, the difference between the number of users seems to be great, but when checking the release date of each VLE (Moodle in 2002 and Canvas in 2011), this difference can be understood: Canvas is a newer platform, with only five years of existence, is already used by more than 2,000 educational institutions worldwide in more than 40 countries, including the United States, Australia, Hong Kong, the United Kingdom, including Brazil, where there are more than 100 institutions using it.

Step 2: The result of this step is presented in item 2.1 of the theoretical reference in the article.

Step 3: The data collected in this step and the analyzes, are presented according to the five technological parameters presented in the methodology of this study. It is worth mentioning that the version of Moodle used by this research was 3.2. Regarding Canvas can not specify the version, due to this VLE has its updates made periodically with calendar pre-established by its developers. From this calendar, all the programmers of Canvas design their own customizations, creating alternative versions with a greater frequency and, there is not a need for a physical server. Therefore, Canvas 
does not work with a fixed version. This versatility is due to the fact that their hosting is in the clouds. To facilitate the understanding of the comparison of the technological parameters of these VLE, it was decided to do so by means of the following tables:

\section{1) Interoperability}

In order to analyze this item, 15 aspects identified in the studies of [10] and [11] on software interoperability were extracted. Thus, Table I was elaborated.

TABLE I: THE PARAMETER OF INTEROPERABILITY IN COMPARING MOODLE AND CANVAS

\begin{tabular}{|c|c|c|c|c|}
\hline \multirow{2}{*}{ Aspects related to Interoperability } & \multicolumn{2}{|c|}{ Moodle } & \multicolumn{2}{|c|}{ Canvas } \\
\hline & Yes & No & Yes & No \\
\hline $\begin{array}{l}\text { Is it possible to integrate } \\
\text { teacher-student, tutor-student and } \\
\text { student-student? }\end{array}$ & $\mathrm{x}$ & & $\mathrm{x}$ & \\
\hline Is there a collaborative content? & $\mathrm{x}$ & & $\mathrm{x}$ & \\
\hline Is it possible the reuse of information? & $\mathrm{x}$ & & $\mathrm{x}$ & \\
\hline $\begin{array}{l}\text { Is it possible to integrate various areas } \\
\text { of knowledge? }\end{array}$ & $\mathrm{x}$ & & $\mathrm{x}$ & \\
\hline Is there an identification function? & $\mathrm{x}$ & & $\mathrm{x}$ & \\
\hline Is there an authorized function? & $\mathrm{x}$ & & $\mathrm{x}$ & \\
\hline Is there a security function? & $\mathrm{x}$ & & $\mathrm{x}$ & \\
\hline $\begin{array}{l}\text { Is there an implementation of } \\
\text { communication and sharing? }\end{array}$ & $\mathrm{x}$ & & $\mathrm{x}$ & \\
\hline $\begin{array}{l}\text { Is it possible linking it to other } \\
\text { applications? }\end{array}$ & $\mathrm{x}$ & & $\mathrm{x}$ & \\
\hline $\begin{array}{l}\text { Is the system developed in different } \\
\text { programming languages? }\end{array}$ & $\mathrm{x}$ & & $\mathrm{x}$ & \\
\hline Is it possible to work on any platform? & $\mathrm{x}$ & & $\mathrm{x}$ & \\
\hline $\begin{array}{l}\text { Do they send and receive information } \\
\text { to each other? }\end{array}$ & $\mathrm{x}$ & & $\mathrm{x}$ & \\
\hline Is there a Javascript language? & $\mathrm{x}$ & & $\mathrm{x}$ & \\
\hline $\begin{array}{l}\text { Is the web architecture presenting the } \\
\text { state transfer? }\end{array}$ & $\mathrm{x}$ & & $\mathrm{x}$ & \\
\hline Are there design patterns? & $\mathrm{x}$ & & $\mathrm{x}$ & \\
\hline
\end{tabular}

As it seems, both VLE presented the same results for all aspects of interoperability. Therefore, it can be stated that both Moodle and Canvas have all the attributes described by the authors that define the interoperability parameter.

\section{2) Usability}

The selected aspects that allow evaluating the usability of software had as references the definitions of the authors [12], [13] and [14]. These aspects are set out in Table II.

TABLE II: THE PARAMETER OF USABILITY IN COMPARING MOODLE AND

\begin{tabular}{|c|c|c|c|c|}
\hline \multicolumn{5}{|c|}{ CANVAS } \\
\hline \multirow{2}{*}{ Aspects related to Usability } & \multicolumn{2}{|c|}{ Moodle } & \multicolumn{2}{|c|}{ Canvas } \\
\hline & Yes & No & Yes & No \\
\hline Is there an efficient interface? & $\mathrm{x}$ & & $\mathrm{x}$ & \\
\hline Is there a friendly interface? & $\mathrm{x}$ & & $\mathrm{x}$ & \\
\hline Is it easy to navigate? & & $\mathrm{x}$ & $\mathrm{x}$ & \\
\hline $\begin{array}{l}\text { Are there properly tools for visual } \\
\text { special needs? }\end{array}$ & & $\mathrm{x}$ & & $\mathrm{x}$ \\
\hline $\begin{array}{l}\text { Are there properly tools for auditory } \\
\text { special needs? }\end{array}$ & & $\mathrm{x}$ & & $\mathrm{x}$ \\
\hline $\begin{array}{l}\text { Is it possible to conclude activities } \\
\text { efficiently? }\end{array}$ & $\mathrm{x}$ & & $\mathrm{x}$ & \\
\hline Is it visually attractive to users? & & $\mathrm{x}$ & $\mathrm{x}$ & \\
\hline Is it intuitive? & & $\mathrm{x}$ & $\mathrm{x}$ & \\
\hline Are the tools easy to use? & $\mathrm{x}$ & & $\mathrm{x}$ & \\
\hline Is it easy to learn? & $\mathrm{x}$ & & $\mathrm{x}$ & \\
\hline Is it easy to use? & $\mathrm{x}$ & & $\mathrm{x}$ & \\
\hline Is it easy to record the steps by steps? & - & & $\mathrm{x}$ & \\
\hline $\begin{array}{l}\text { Are there any errors while using the } \\
\text { software? }\end{array}$ & - & & $\mathrm{x}$ & \\
\hline
\end{tabular}

Although it is possible to observe that in this item the
Canvas has obtained a better classification than Moodle, having a layout that favors the navigation of the user and being considered more intuitive than Moodle, the two VLE presented a clear and easy understandable interface. For example, by navigating through all the tabs on the activities of the two VLE it was possible to distinguish the functions and utilities during the course. In this way, the VLE are well accepted by their users and, the clarity of a software inspires confidence and captivates the use [14].

Still on navigation, the Canvas menu allowed navigation in the environment in a more practical way, because it is more colorful, fast, intuitive and easier than in Moodle that initially requires the user to define their colors, windows and images. Thus, Canvas offers a more intuitive and pleasurable way during access because its platform already presents itself in this way.

With regard to support for students with special needs, either visual or auditory, both platforms do not offer specific support of the system itself. It was also verified that in both VLE the activities can be completed effectively by users (either by questionnaire, forum, file sending, among others), through a simple step-by-step and without presenting errors in the system at the moment of conclusion.

\section{3) Performance}

In order to analyze this technological parameter, the definitions proposed by [15] were used and, based on these definitions, Table III was elaborated.

TABLE III: THE PARAMETER OF PERFORMANCE IN COMPARING MOODLE

\begin{tabular}{|c|c|c|c|c|}
\hline \multicolumn{5}{|c|}{ AND CANVAS } \\
\hline \multirow{2}{*}{ Aspects related to Performance } & \multicolumn{2}{|c|}{ Moodle } & \multicolumn{2}{|c|}{ Canvas } \\
\hline & Yes & No & Yes & No \\
\hline $\begin{array}{l}\text { Is it possible to follow the } \\
\text { interactions between } \\
\text { teacher-student; tutor-student and } \\
\text { student-student? }\end{array}$ & $\mathrm{x}$ & & $\mathrm{x}$ & \\
\hline $\begin{array}{l}\text { Are there tools which show the } \\
\text { quantitative attendance of the } \\
\text { students? }\end{array}$ & $\mathrm{x}$ & & $\mathrm{x}$ & \\
\hline $\begin{array}{l}\text { Are there tools showing the } \\
\text { qualitative interactions among } \\
\text { students? }\end{array}$ & & $x$ & & $\mathrm{x}$ \\
\hline $\begin{array}{l}\text { Is it possible to quantify the amount } \\
\text { of posts in forums? }\end{array}$ & $\mathrm{x}$ & & & $\mathrm{x}$ \\
\hline $\begin{array}{l}\text { Is it possible to verify the relevance } \\
\text { of the message? }\end{array}$ & & $\mathrm{X}$ & & $\mathrm{x}$ \\
\hline $\begin{array}{l}\text { Is it possible to verify the amount of } \\
\text { time between each post? }\end{array}$ & & $\mathrm{x}$ & & $\mathrm{x}$ \\
\hline $\begin{array}{l}\text { Is it possible to quantify the amount } \\
\text { of accesses? }\end{array}$ & $\mathrm{x}$ & & $\mathrm{x}$ & \\
\hline
\end{tabular}

On the evaluation of the performance of these VLE, it was possible to observe that the performance of Moodle and the Canvas are very similar, only in the item Is it possible to quantify the amount of posts in forums? There was a divergence: only Moodle presents quantitative resource of analysis of the participants, while in Canvas this resource was not identified. Given this, there may be a limitation in the access monitoring and interaction of the student in the virtual environment, and may compromise the performance of this.

\section{4) Digital tools for learning}

To analyze this technological parameter, it was selected eight aspects that were based on the definition of digital tools described by [16]. After determining these aspects, both VLE 
were evaluated and compared. The results are shown in Table IV.

TABLE IV: THE PARAMETER OF DigitAL TOOLS IN COMPARING MOODLE AND CANVAS

\begin{tabular}{|c|c|c|c|c|}
\hline \multirow{2}{*}{$\begin{array}{l}\text { Aspects related to learning digital } \\
\text { tools }\end{array}$} & \multicolumn{2}{|c|}{ Moodle } & \multicolumn{2}{|c|}{ Canvas } \\
\hline & Yes & No & Yes & $\mathrm{No}$ \\
\hline $\begin{array}{l}\text { Is it possible holding } \\
\text { teleconference? }\end{array}$ & & $\mathrm{x}$ & $\mathrm{x}$ & \\
\hline $\begin{array}{l}\text { Is it possible holding } \\
\text { videoconference? }\end{array}$ & $\mathrm{x}$ & & $\mathrm{x}$ & $\mathrm{x}$ \\
\hline Is there chatting possibility? & $\mathrm{x}$ & & $\mathrm{x}$ & $\mathrm{x}$ \\
\hline Is there environment for forum? & $\mathrm{x}$ & & $\mathrm{x}$ & $\mathrm{x}$ \\
\hline Are there e-mails? & $\mathrm{x}$ & & $\mathrm{x}$ & $\mathrm{x}$ \\
\hline Are there interactive media? & $\mathrm{x}$ & & $\mathrm{x}$ & $\mathrm{x}$ \\
\hline Are there game functions? & & $\mathrm{x}$ & $\mathrm{x}$ & \\
\hline $\begin{array}{l}\text { Is it possible having access to other } \\
\text { applications in the environment? }\end{array}$ & & $\mathrm{x}$ & $\mathrm{x}$ & \\
\hline
\end{tabular}

The result found here, allow concluding that Moodle did not present the resource for the teleconference, use of games and the possibility of having access to other applications within the program. Thus, in this technological parameter, the Canvas stood out. Then, it presents more resources available to the users.

\section{5) Management tools}

In order to analyze this technological parameter, nine aspects were evaluated and the results are presented in Table V. It is worth mentioning that to determine each of these aspects we considered the studies on management tools [16].

TABLE V: THE PARAMETER OF MANAGEMENT TOOLS IN COMPARING MOODLE AND CANVAS

\begin{tabular}{|c|c|c|c|c|}
\hline \multirow{2}{*}{$\begin{array}{c}\text { Aspects related to management } \\
\text { tools }\end{array}$} & \multicolumn{2}{|c|}{ Moodle } & \multicolumn{2}{|c|}{ Canvas } \\
\hline & Yes & No & Yes & No \\
\hline Is there the function for notes? & $\mathrm{x}$ & & $\mathrm{x}$ & \\
\hline $\begin{array}{l}\text { Is there the function for lesson } \\
\text { plans? }\end{array}$ & & $\mathrm{x}$ & $\mathrm{x}$ & $\mathrm{x}$ \\
\hline $\begin{array}{l}\text { Is there the function for preparing } \\
\text { activities? }\end{array}$ & $\mathrm{x}$ & & $\mathrm{x}$ & \\
\hline $\begin{array}{l}\text { Is there the function for following } \\
\text { the students interactions? }\end{array}$ & $\mathrm{x}$ & & $\mathrm{x}$ & \\
\hline $\begin{array}{l}\text { Is there the function for accessing } \\
\text { grades? }\end{array}$ & $\mathrm{x}$ & & $\mathrm{x}$ & \\
\hline $\begin{array}{l}\text { Is there a function for viewing the } \\
\text { school history? }\end{array}$ & & $\mathrm{x}$ & $\mathrm{x}$ & $\mathrm{x}$ \\
\hline $\begin{array}{l}\text { Are there tools for updating the } \\
\text { contents? }\end{array}$ & & $\mathrm{x}$ & - & $\mathrm{x}$ \\
\hline $\begin{array}{l}\text { Is there displaying of notes and } \\
\text { activities? }\end{array}$ & $\mathrm{x}$ & & $\mathrm{x}$ & \\
\hline $\begin{array}{l}\text { Does it allow generating statistical } \\
\text { reports? }\end{array}$ & $\mathrm{x}$ & & $\mathrm{x}$ & \\
\hline
\end{tabular}

Regarding the management tools (Table V) both VLE presented similar characteristics. In addition, in both virtual environments were detected the lack of three important aspects: the function to elaborate lesson plans, option to visualize the students' academic history and dissemination of the grades by activities.

The two VLE analyzed have Warnings available, which is a virtual space in which the teacher and / or tutor can communicate more directly with the students, giving them information about what is happening in the course.

Another conclusion that could be reached is that in both VLE the administrator of the VLE, that is, the person responsible for making the course available can use several ways of inserting the contents. Since in Moodle there are two types of fields for insertion of content: resources and activities. Resources are used to demonstrate content to students, and activities are tools for assessment and communication with students. Moodle has as evaluation tools for students the journal, database, chat, poll, forum, glossary, lesson, evaluation research, questionnaire, task submission and wiki. Canvas has the activities of sending tasks, discussions (forum), collaborations (wikis), conferences, and there is still the possibility of incorporating applications.

In both VLE it is possible to follow the students' participation. In addition to the teacher or tutor having the possibility of doing this monitoring through interactions in the forum, messages to clear questions, and participation in activities, it is possible to extract information from the Canvas and Moodle database in the form of reports, which allow to verify the participation and interaction between the learning subjects. The two environments also allow following the production of students within the VLE (tasks performed). Regarding the grades, in both VLE, the student can follow up with access to a report of his grades, as well as the feedback of his activities.

As far as the academic record is concerned, there is no specific space within the two environments that the student has access to. This document is usually made available in a specific academic system of the institution.

There is also no specific tool for updating the content in the analyzed environments. In this case, the mediator in the environment must pay attention to the analysis and choice of contents that use a variety of digital resources, and that mainly achieve the proposed objective.

Regarding the statistical reporting, both Canvas and Moodle have some types of reports available for course management and pedagogical mediation. Canvas has a student report, student group report, task report, and report notes. In the discussion environment you can still see whether the messages have been read or not. In Moodle, the following types of reports were found: access, active logs, activities (shows the number of visits in each environment resource), participation in activity (shows what activities the student has accessed and their actions), completion of activities (shows which activities were completed or not by the student) and grades.

\section{CONCLUSION}

Due to the development and advancement of Digital Information and Communication Technologies, VLE have been presented as potential learning tools, in particular Moodle and Canvas, which according to this study, positively noted most of its technological parameters required by software.

At the end of the research it was possible to observe that both AVA present similar evaluations. However, Canvas was more complete, collaborative and with a very intuitive interface to the results analyzed, in relation to Moodle.

In addition, Canvas uses a programming language more modern than Moodle, presenting an updated technology: cloud computing, which represents an advantage over Moodle. Canvas is designed to work in the cloud, that is, it does not need hosting, nor upgrades, versions, data back-up, nor is it harmed when the servers fail. This way, users access 
it through the Web.

Another feature that is a differential on Canvas is how it displays the score or percentage of students' grades, or note by letter, or Grade Point Average (GPA) scale. GPA is a grading scale used in the US to measure student performance in studies and is used to compare student performance on a scale. The Canvas report can also show the teacher the variation of grades by classes and students, making this monitoring more personalized.

It is worth mentioning that one of the difficulties encountered in the execution of this study was the determination of the evaluation parameters among VLE, since there are few published works that mention the software comparison. What we found were just commercial software comparison sites and they do not have users' usability assessment and descriptions as to their potential in relation to other technologies other than commercial comparisons. And this hinders the work of those who propose to choose a virtual learning environment and have no domain regarding software.

Therefore, it is suggested that the developers of these environments create a Channel of Communication between the company and the user in order to co-create value and ensure that any professional of the interested area has facility to choose the most appropriate VLE.

\section{FUTURE WORK}

A new step is to choose a course and implement it in two virtual learning environments: moodle and Canvas. Offer them to the same class of students. Ask the students to evaluate the two environments according to the five technological parameters: Interoperability; Usability; Performance; Digital tools for learning and, Management tools. In the end check which one had the best ratings.

\section{REFERENCES}

[1] ABED. (2014). Associação Brasileira de Educação a Distância. Censo EAD.BR: Relatório analítico da aprendizagem a distância no Brasil /2014. [Online]. Available: http://www.adeb.org.br/censoead/CensoEAD2014_portugues.pdf

[2] ABED. (2015). Associação Brasileira de Educação a Distância. Censo EAD.BR: Relatório analítico da aprendizagem a distância no Brasil /2015. [Online]. Available: http://abed.org.br/arquivos/Censo_EAD_2015_POR.pdf

[3] M. G. Moore and G. Kearsley, Educação a distância: Uma Visão Integrada, São Paulo: Thomson Learning, 2007.

[4] J. Mattar, "Guia de educação a distância," São Paulo: Cengage Learning, Portal Educação, 2011.

[5] ] I. M. M. S. Silva. (2009). Ambiente virtual de aprendizagem na educação a distância. [Online]. Available: http://www.conahpa.org/wp-content/themes/Conahpa/papers/final98.p df.

[6] P. Lévy, As tecnologias da inteligência: o futuro do pensamento na era da informática, São Paulo, 1993.

[7] R. Tori, Educação sem Distância: As Tecnologias Interativas na Redução de Distâncias em Ensino e Aprendizagem, São Paulo: Editora Senac, 2010.

[8] J. Mattar, "Interatividade e aprendizagem," Educação a Distância: $O$ Estado da Arte, São Paulo: Pearson, 2009, pp. 112-120.

[9] J. A. Valente, "Educação a distância no ensino superior: sugestões e flexibilizações," Interface, vol. 7, no. 12, pp. 139-142, 2003.

[10] D. Dicheva and V. Dimitrova. (2008). Semantic web and intelligent learning environments. The 9th International Conference on Intelligent
Tutoring Systems (ITS), Montreal. [Online]. Available: https://comparisons.financesonline.com/canvas-lms-vs-moodle

[11] I. I. B. S. Pinto. (2009). Um modelo computacional para a construção de sistemas educacionais adaptativos e semânticos. [Online]. Available: http://dominiopublico.gov.br/pesquisa/DetalheObraForm.do?Select_a ction=\&co_obra $=174287$

[12] K. Buttignon et al., "Aplicação da norma ISO 9241 para o desenvolvimento de Interfaces Interativas, Eficientes e Agradáveis em ambientes EAD (Ensino a Distância)," Revista Científica on-line-Tecnologia, Gestão e Humanismo, vol. 1, no. 1, pp. 33-46, 2012.

[13] A. C. Souza. (2004). Proposta de um processo de avaliação da usabilidade de interfaces gráficas de sistemas interativos computacionais, através da integração das técnicas prospectiva, analítica e empírica. [Online]. Available: http://repositorio.ufsc.br/xmlui/handle/123456789/87086.

[14] J. Nielsen and T. K. Landauer, "A mathematical model of the finding of usability problems," in Proc. the INTERACT '93 and CHI '93 Conference on Human Factors in Computing Systems (CHI '93), New York, NY, USA: ACM, 1993.

[15] M. G. Moore, "Three types of interaction," The American Journal of Distance Education, vol. 3, no. 2, pp. 1-6, 1989.

[16] M. G. R. Grossi, A. L. Moraes, and A. T. Brecia, "Interatividade em Ambientes virtuais de Aprendizagem no processo de ensino e aprendizagem na Educação a Distância," Revista @rquivo Brasileiro de Educação, Belo Horizonte, vol. 1, no. 1, pp. 75-92, 2013.

[17] Moodle Partner. (2017). About moodle. [Online]. Available: https://moodle.org/

[18] Canvas LMS 4. (2017). [Online]. Available: https://www.canvaslms.com

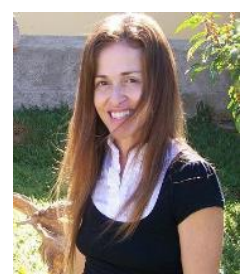

Márcia Gorett Ribeiro Grossi was born on August 23, 1964, in Brazil. She is Ph.D. in information science from the Federal University of Minas Gerais (Brazil). She is master in technology education from the Federal Center of Technological Education of Minas Gerais. Also, she is electrical engineer from the Pontifical Catholic University of Minas Gerais. She is currently teacher of the Department of Education and of the master's degree in technological education of the Federal Center of Technological Education of Minas Gerais. She is the leader of the AVACEFETMG Research Groupe, whose research interests are virtual learning environments.

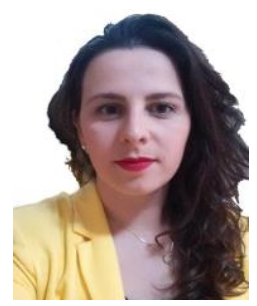

Michelle Cristina Almeida de Souza Elias was born on October 13, 1986, in Brazil. She is master in electrical engineering from the State University of Campinas (UNICAMP). She studied clinical engineering and biomedical engineering at the National Institute of Telecommunications teaching institution. She works in the company ORIENTE academic works. She is a member of the research group AVACEFETMG, whose research interests are virtual learning environments.

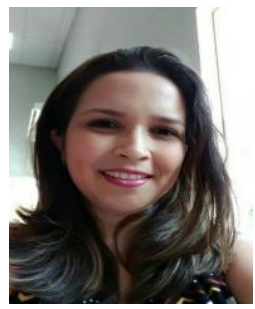

Camila Macedo Chamon was born on June 14 1989, in Brazil. She is a master's student in the post-graduation program in technological education of the Federal Center of Technological Education of Minas Gerais. Also, she is graduated in pedagogy from the School of Education of the Federal University of Minas Gerais. She is a member of the research group AVACEFETMG, whose research interests are virtual learning environments.

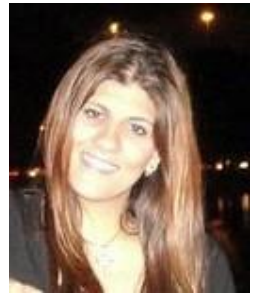

Débora Cristina Cordeiro Campos Leal was born on October 31, 1981, in Brazil. She is a master's student in the post-graduation program in technological education of the Federal Center of Technological Education of Minas Gerais. She is graduated in pedagogy from Federal University of Lavras. She is specialist in planning, implementation and management of distance education from Universidade Federal Fluminense.

She is a member of the research group AVACEFETMG, whose research interests are virtual learning environments. 